\title{
Oxford
}

\section{Peaceable Kingdom}

\section{Stability and Change in Modern Britain}

BRIAN HARRISON, Corpus Christi College, Oxford. From suffragist violence to recreational change, this social and political history tackles many topics central to an understanding of British polities and social behavior since the $1780 \mathrm{~s}$.

September $1982 \quad 464$ pp. $\$ 45.00$

\section{Exile Politics During the Second World War}

The German Social Democrats in Britain

ANTHONY GLEES, Brunel University. This book examines the politics of the German Social Democratic Party during its exile in England, thus illuminating the wartime policy-making of the Foreign Office and the Labour Party. (Oxford Historical Monographs) August $1982 \quad 284 \mathrm{pp} . \quad \$ 39.95$

\section{The Oxford Economists in the Late Nineteenth Century}

ALON KADISH, Hebrew University of Jerusalem. This outstanding example of intellectual history provides a new perspective on the development of the study of economics in Britain. The theoretical debate is considered within the context of institutional and organizational developments. (Oxford Historical Monographs)

August $1982 \quad 400$ pp. $\$ 45.00$

\section{Peel, Priests, and Politics}

Sir Robert Peel's Administration and the

Roman Catholic Church in Ireland 1841-1846

DONAL A. KERR, Maynooth College, Ireland. An objective account of how one of England's greatest prime ministers, at the height of his power, made a serious attempt to solve the "Irish problem," in which political and religious elements were inextricably mixed. (Oxford Historical Monographs)

October $1982 \quad 416 \mathrm{pp} . \quad \$ 49.50$

\section{Parliaments and English Politics}

CONRAD RUSSELL, Yale University. "The strength of Russell's book... lies in what it tells us about the parliaments of the $1620 \mathrm{~s}$ considered by themselves.... His lively and provocative account of these assemblies reflects a mastery of the abundant published and manuscript sources... and provides us with a model of how parliamentary history should be written." - Albion. Now available in paperback.

1979 (paper 1982) $453 \mathrm{pp}$. cloth $\$ 48.00$ paper $\$ 19.95$ 


\section{New From Allen \& Unwin}

WAR AND THE STATE

The Transformation of British Government, 1914-1919

Kathleen Burk, Ed.

World War I saw the scope of governmental intervention widened in an unprecedented manner. WAR AND THE STATE gives an insight into British central government in 1914, how and why it altered during the war years; and what permanent changes remained when the war was over, thus providing the first modern study of the origins of the modern British state.

Cloth-\$29.50

1982

\section{NORTHAMPTON: Patronage And Policy At The Court Of James I}

Linda Levy Peck

Drawing extensively on Northampton's papers, hitherto largely overlooked. the author presents a more balanced assessment of this important Jacobean courtier who shaped policy and pursued administrative reform as avidly as he sought his own patronage and profit.

Cloth-\$37.50

December 1982

THE NONCONFORMIST CONSCIENCE: Chapel and Politics, 1870-1914

David W. Bebbington

"After using the phrase 'the nonconformist conscience' so long, historians may now turn to Bebbington's work for a clear definition and description of the phenomenon ... crammed with information ... well-organized ... solid piece of work..." Cato

Cloth-\$22.50

\section{AUGUSTAN ENGLAND}

New In Spring 1983

Geoffrey Holmes

An authoritative study of the professional classes before the Victorian Age.

\section{Ther England's Architects}

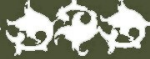

\section{EDWIN LUTYENS}

\section{Architect Laureate}

Roderick Gradidge

Wit fin the last few years... his reputation has surged to its current prominence ... Gradidxe's bork is a surver of Lutyens maior wirks. most notably ... of English country homes, many of which are thoroughly described in the text..." Bowitits Cloth. 524.50

\section{ATHENIAN STUART}

Pioneer of the Greek Revival

David Watkin

It has been said that lames. "Athenian" Stuart (1713-88) was the father of the countless Greek style buildings which. with their austere lines and Duric porticos, stretch from Edinburah to Cortu, from Moscow to Savanah

Cloth-\$21.95 Paper-59.95

Fall 1082

Stucties in Architecture No. I

\section{WILLIAM TALMAN}

Maverick Architect

John Harris

An idosyncratic and highly original talent and contemporary of Wren, Hawksmowr. and Vanbrugh. Talman $(1650-1710$, was the leading country house architect of the Court of William IIt

Clith. $\$ 21$ as Taper-\$9.05

Fall 1982

Studies in Architecture No. 2

Future Studies will deal with Robert Taylor and Axel Hais

\section{Allen \& Unwin Inc.}

